\title{
USE OF GPS AND GIS FOR MONITORING OF CATTLE'S GRAZING ON A SILVIPASTURE OF TOLIMA (COLOMBIA)
}

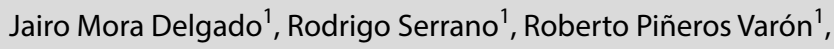
Gisou Díaz ${ }^{2}$

\section{Abstract}

Cattle behavior and grazing distribution is probably related to the available food, although it could also be influenced by the canopy shade, ambient temperature and access to water. The objective of this study was to evaluate the interaction among tree cover (TC) and cattle positions $(\mathrm{CP})$ when searching for food and comfort areas, under warm and hot weather, in a silvopasture system. Analyses were conducted on Pajonales farm, located in the municipality of Ambalema (lat. $4^{\circ} 45^{\prime} 25.9^{\prime \prime} \mathrm{N} ; 4^{\circ}$ 52' 20.8” W) in Colombia, from December 2009 to January 2010. The farm has an average elevation of 300 masl. Mean precipitation is 1270 mm.year- ${ }^{1}$, and temperature $28^{\circ} \mathrm{C}$. The pasture used for this study had an area of approximately 54 ha, with topography from flat to gently sloping. TC was determined from digital orthophotos QuickBird using ArcGIS ${ }^{\circledR}$ 9.1. The paddock was segmented into a 0.25 ha grid cell lattice and all sapling canopies within grid cells and animal movement were mapped. Six cows (3 Brahman and $3 \mathrm{~F} 1$, Brahman $\mathrm{x}$ Holstein) equipped with GPS-collars (Garmin eTrex-Vista) configured to record and store position, were tracked during 60 days at 5-min intervals. Average values indicate that cows, generally, traveled greater distances in warm period $(7.4 \mathrm{~km})$ and 6.1 $\mathrm{km}$ in the hot period. Cows prefer areas with low TC $(<20 \%)$ and intermediate TC (20-40\%); these areas had more biomass of fodder dry matter. The study is an important contribution to understanding the dynamics of animals in search for food under grazing conditions.

Key words: animal behaviour, agroforestry, remote sensors, ruminants.

1 Livestock Production Department, Universidad del Tolima. Research Group at Sistemas Agroforestales Pecuarios, Universidad del Tolima. Corresponding author: jrmora@ut.edu.co

2 Statistics and Mathematics Department, Sistemas Agroforestales Pecuarios 


\section{Uso de GPS y SIG para el monitoreo del pastoreo de ganado en una silvopastura del Tolima (Colombia)}

Jairo Mora Delgado, Rodrigo Serrano, Roberto Piñeros Varón, Gisou Díaz

\section{Resumen}

El comportamiento del ganado y la distribución del pastoreo puede estar relacionado a los alimentos disponibles, aunque también podría influir el dosel forestal, la temperatura ambiente y el acceso al agua. El objetivo de este estudio fue evaluar la interacción entre la cobertura arbórea (CA) y la ubicación del ganado (UG) cuando buscan una zona para comer y estar cómodos, en climas templados y cálidos, en un sistema de silvopastoril. El análisis se realizó en la finca Pajonales, ubicada en el municipio de Ambalema (lat $4^{\circ} 45$ '25 .9 " $\mathrm{N}$; $74^{\circ} 52$ '20.8' W) en Colombia, desde diciembre de 2009 hasta enero de 2010. La finca tiene una elevación promedio de $300 \mathrm{msnm}$. La precipitación es $1270 \mathrm{~mm}$. año- 1 , y la temperatura es de $28^{\circ} \mathrm{C}$. El pasto utilizado para este estudio tenía un área de aproximadamente 54 ha, con una topografía plana, hasta una pendiente suave. La CA se determinó a partir de las ortofotos digitales QuickBird utilizando ArcGIS ${ }^{\odot}$ 9.1. El potrero se dividió en un entramado en cuadricula de 0.25 ha y se cartografió el dosel de todos los árboles jóvenes dentro del entramado y el movimiento del animal. Se rastrearon seis vacas (3 Brahman y $3 \mathrm{~F} 1$, Brahman x Holstein) equipadas con collares de localización satelital (Garmin eTrex-Vista) configurados para registrar y almacenar la posición, durante 60 días a intervalos de 5 minutos. Los valores promedio indican que las vacas, en general, viajaron distancias mayores en el periodo de clima templado $(7,4 \mathrm{~km})$ y $6,1 \mathrm{~km}$ en el período cálido. Las vacas prefieren las áreas con poca CA $(<20 \%)$ e intermedio CA (20-40\%); Estas áreas tenían más biomasa de follaje. El estudio es una contribución importante para comprender la dinámica de los animales en la búsqueda de alimentos en condiciones de pastoreo. 


\section{USO DO GPS E GIS PARA CONTROLAR 0 APASCEN- TAMENTO DE GADO NAS ÁREAS DE SILVIPASTAGEM DO TOLIMA (COLÔMBIA)}

Jairo Mora Delgado, Rodrigo Serrano, Roberto Piñeros Varón, Gisou Díaz

\section{Resumo}

O comportamento do gado e a distribuição do apascentamento podem estar relacionados aos alimentos disponíveis, embora também podem ser afetadas pelo dossel florestal, a temperatura ambiente e o acesso à água. O objetivo deste estudo foi avaliar a interação entre a cobertura de árvores (CA) e localização de gado (LG) na busca de uma área para comer e permanecer confortável em climas temperados e quentes, num sistema de silvipastagen. A análise foi realizada na fazenda Pajonale, localizada no município de Ambalema (lat $4^{\circ} 45^{\prime} 25,9^{\prime \prime} \mathrm{N} ; 74^{\circ} 52^{\prime} 20,8^{\prime \prime} \mathrm{O}$ ) na Colômbia, de dezembro de 2009 a janeiro de 2010. A fazenda possui uma elevação média de 300 metros acima do nível do mar. A precipitação média anual é de $1270 \mathrm{~mm}$, ano-1, e a temperatura é de $28^{\circ} \mathrm{C}$. O pasto usado para este estudo tinha uma área de aproximadamente 54 ha, com uma topografia plana a um declive suave. A CA foi determinada a partir das ortofotos digitais QuickBird usando o ArcGIS ${ }^{\circ}$ 9.1. O potreiro foi dividido em uma estrutura de reticulado de 0,25 ha e o dossel de todas as árvores jovens dentro da estrutura e movimento do animal foi mapeado. Foram rastreadas seis vacas (3 Brahman e 3 F1, Brahman x Holstein) equipadas com colares de localização por satélite (Garmin eTrex-Vista) configurados para registrar e armazenar a posição durante 60 dias a intervalos de 5 minutos. Os valores médios indicam que as vacas, em geral, percorreram maiores distâncias no período de clima temperado $(7,4 \mathrm{~km})$ e $6,1 \mathrm{~km}$ no período quente. As vacas preferem áreas com pouco CA (< $20 \%)$ e CA intermédio (20-40\%). Essas áreas tinham mais biomassa de folhagem. O estudo é uma importante contribuição para o entendimento da dinâmica dos animais na busca por alimentos em condições de pastejo. 


\section{Introduction}

On tropical regions, the temperature is perhaps the most important climatic factor, but others factor can influence grazing distribution. Daily, the large herbivore must decide where to graze, rest and drink(1). They use grazing patterns in function of different king of resources biotic and abiotic; those resources include distance and allocation of water, slope and weather. Others factors include quality and quantity of fodder and tree cover as shade (2).

Global Positioning System (GPS) have been usually used to study animal behavior on range systems, mainly to quantify positions and movements of cattle and others ungulate species, and derive measurements about their grazing and resting activities $(3,4,5)$.

Different studies have obtained data using a varied number of animals equipped with GPS acopled to collars, depending on the research objectives. Thus, studies in the USA used six collars and other study in Israel used two collars (6); Also, Mora-Delgado (7) has used six collars to study the preference of the animals for grazing sites at paddock scale. Ganskopp use 4 collars for each group of animals (8) and Schwager (9) used 3 collared cows to categorize animal tracking data into various classes of behavior. As well, other studies have used a greater number of collars, which implies higher costs.

When a small number of devices are used, the increase in sampling is necessary. In this regard, in the study of Ungar et al. (6) two GPS collars were deployed, one in each paddock; they were moved from one cow to another twice a week to increase the cow sample size.

In addition, with the implementation of differential correction in data from GPS collars, accuracy will increase by about an order of magnitude, with an expected $95 \%$ confidence interval of about $12 \mathrm{~m}$, (10) some studies found a radius of 5.5 $\mathrm{m}$ from the mean locale, encompasses $90 \%$ of the coordinates (11).

The study of Liu et al. (12) suggest that a small subset group may be adequate for identifying areas visited by cattle and larger subset group size (e.g. subset group containing more than $75 \%$ of animals) is recommended to achieve better accuracy of group movement characteristics and spatial occupancy for the use of correlating cattle locations with other environmental factors.

In Colombia, there is a little information about the interaction between tree cover and cattle behavior, using remote sensor. Thus, this study aimed at evaluating the movement of cattle grazing under different biotic (tree cover and fodder supply) and abiotic factors (ambient temperature) for searching for food and comfort areas, under warm and hot periods, in a silvopastoral system, using GPS in an SIG ambient.

\section{Materials and methods}

Analyses were conducted in Pajonales farm, located in the municipality of Ambalema (lat. $4^{\circ} 45^{\prime} 25.9^{\prime} \mathrm{N}$; $74^{\circ} 52^{\prime} 20.8^{\prime \prime}$ 
W) in Colombia, from December 2009 and January 2010. It has an average elevation of 300 masl. Mean precipitation is 1270 mm.year- ${ }^{1}$. The data of precipitation and air temperature in the study area were monitoring during December (2009) and January (2010) by the weather station Pajonales Company SA.

A paddock of 54 ha was used for this study, consisting of five ranges of tree cover (TC): Poor $(\leq 20)$, Low $(\geq 20 \% \leq 40 \%)$, Intermediate $(\geq 40 \% \leq 60 \%)$, High $(\geq 60 \%$ $\leq 80 \%)$ and Very High ( $\geq 80 \%)$. Each one, corresponding to $47 \% ; 21 \% ; 16 \% ; 12 \%$ and $4 \%$ of the total area, respectively. Topography was flat to gently sloping. There were two drinking water locations on the south-east end of this pasture. TC was determined from digital orthophotos Quick Bird using a software ArcGIS ${ }^{\circledast} 9.1$ of the Universidad Nacional de Colombia. Estimation of the TC was made with Hwths Tools for ArcGIS ${ }^{\circledast} 9.1$ by polygons and after that, these were represented by points $(5 \times 5 \mathrm{~m})$. Thus, the paddock was segmented into a 0.25 ha grid cell lattice, and sapling canopies within grid cells were mapped.

To estimate the biomass production of herbaceous stratum, sampling sites were selected in function of tree cover. For this, the grid superimposed on the satellite image of tree cover was used in a GIS environment, using ArcGIS 9.2. Thus, 19 cells were selected, each of which is $2500 \mathrm{~m} 2$ (Figure 1). In the field, the plots were demarcated and proceeded to estimate biomass, using wooden frames $(50 \times 50 \mathrm{~cm})$, adapting the methodology of Haydock and Shaw (13) and t'Mannetje and Haydock (14). The measurement of biomass was done at different times (twice per dry and twice per rainy period) from 25 November 2009 to December 25, 2010. Forage biomass was expressed in DM.ha-1. 


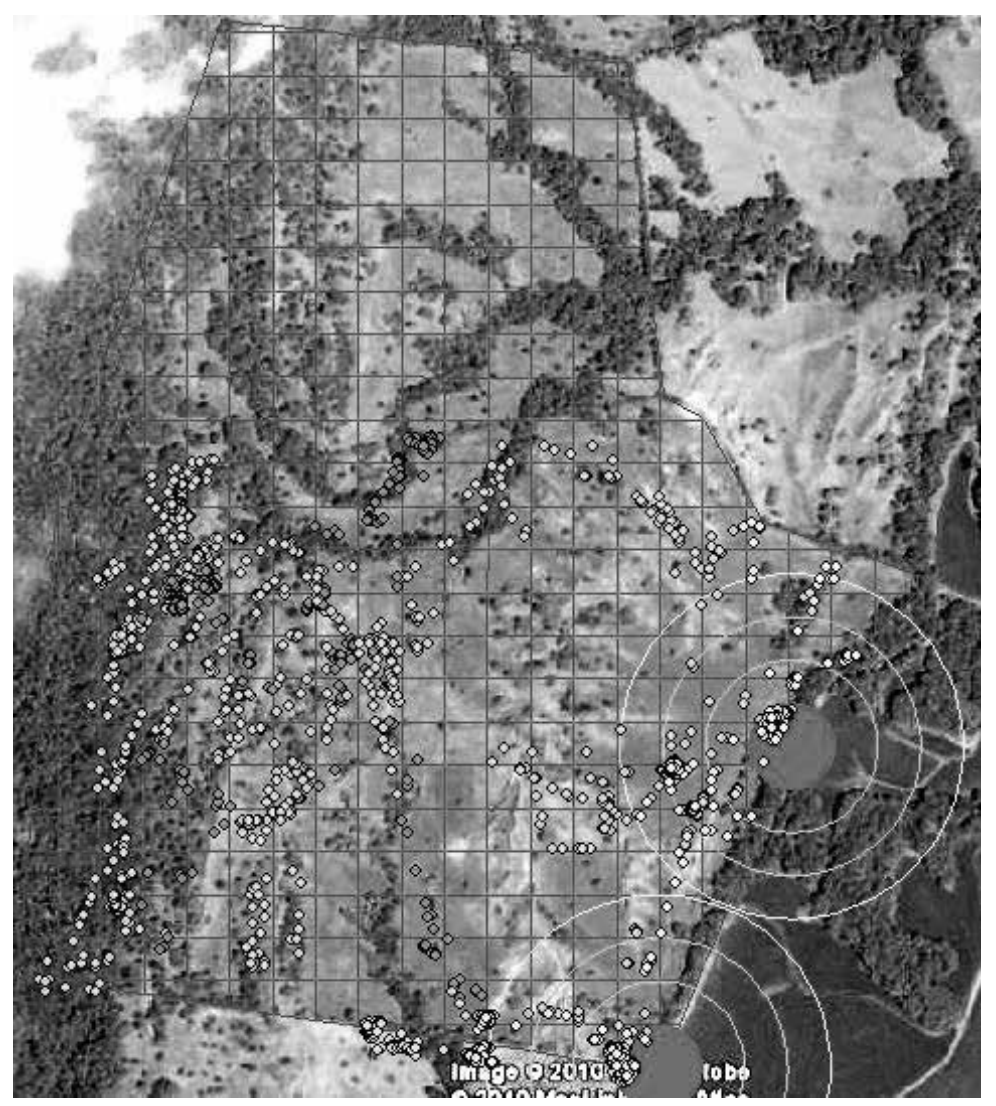

Figure 1. Grid superimposed on the satellite image Quick Bird of tree cover in a GIS environment, using ArcGIS 9.2.

Source: Authors based on satellite image of GoogleEarth, 2010.

Note: Color points indicate positions of cows; the concentric circles were used to determine proximity to the water source at $50,100,150$ and $200 \mathrm{~m}$.

Six cows ( 3 Brahman and 3 F1, Brahman $x$ Holstein; $450 \mathrm{~kg}$ LW) equipped with GPS-collars (Garmin eTrex-Vista) configured to record and store cattle positions (CP), were tracked during 60 days at 5-min intervals. Experimental animals were assigned randomly to each treatment, but the collared cows were assigned randomly to each treatment and they grazed together with a herd of young cows. Visual scans of foraging activities and recording of locations and foraging activity were conducted at 5 minute intervals by 4 trained observers, during 4 daylight periods of 12 hours. Scanned activities were grazing, traveling and resting. Daily travel distance was calculated for each animal in the herd by summing euclidean displacement between positions with a recorded distance and differentially corrected GPS data using ArcGIS 9.3. Distance between positions was compared to visual scans of foraging activities using statistical program Infostat (15). 
The average runs per cow per day were analysed with descriptive statistics. To compare the means of the routes by breed and period, t-Student's test for independent samples was used. To assess the frequency of visits of cows to sources of water, cattle position recorded in a concentric circle (within $50 \mathrm{~m}$ ) around each trough was quantified. These measurements were made in the two days of highest temperature $\left(31.4^{\mathrm{a}} \mathrm{C}\right)$ and the two lower temperatures $\left(27^{\circ} \mathrm{C}\right)$ of the monitoring period.

Based on total CP recorded and processed on a work sheet in excel, a classification of movement of cows was done. For that, using the third quartile as up class limit of the distance $(\mathrm{m})$ registered by GPS in each activity (Resting, Grazing and Traveling) of cows, were defined classes of observed activities. Thus, three classes ( $<4 \mathrm{~m}$, resting; $4-12 \mathrm{~m}$, grazing, and $>12 \mathrm{~m}$, traveling) were obtained. Those class limits were used to classify distances registered with GPS along complete day. After that, a comparison between observed activities with predicted activities was done; these data were statistically analyzed with Chi-square test.

With the t-Student test for independent samples, the daily routes $(\mathrm{km})$ were evaluated by breed composition (F1 and $\mathrm{Br}$ ) and by seasons (warm and hot) for the two days with higher temperatures and the two days with lower temperatures, respectively.

The statistical evaluation for the data of Activity $(T+G)$ and No Activity (R) and the behavior of the cows in relation to the visits to the area of hydration of the paddock, by racial composition and by time, was analyzed with the test of nonparametric comparison of Mann Whitney $\mathrm{U}$ because the analyzed data do not have a normal distribution.

The Pearson correlation coefficient was calculated with the objective to investigate if there is an association between the number of visits (PC) and the tree coverage (TC) and a regression was made to determine the functional relationship between a response variable (CP) and a regression (TC). The data was represented by dispersion diagrams. The statistical analysis was performed with the SPSS v.20 program and regression model was done with Infostat software (15).

\section{Results}

Precipitation accounted $60 \mathrm{~mm}$ on December, while, on January it was only 4.4 $\mathrm{mm}$. On the other hand, average temperature during experimentation period was $29^{\circ} \mathrm{C}$, thus the analysis of mean daily temperature and precipitation allowed to define a posteriori two distinct periods: on December (2009) 25\% of total days were below to the temperature average, while, on January (2010) the $48.4 \%$ of total days presented temperatures above to average. So, we had two different periods: warm days and hot days, respectively (Figure 2). 

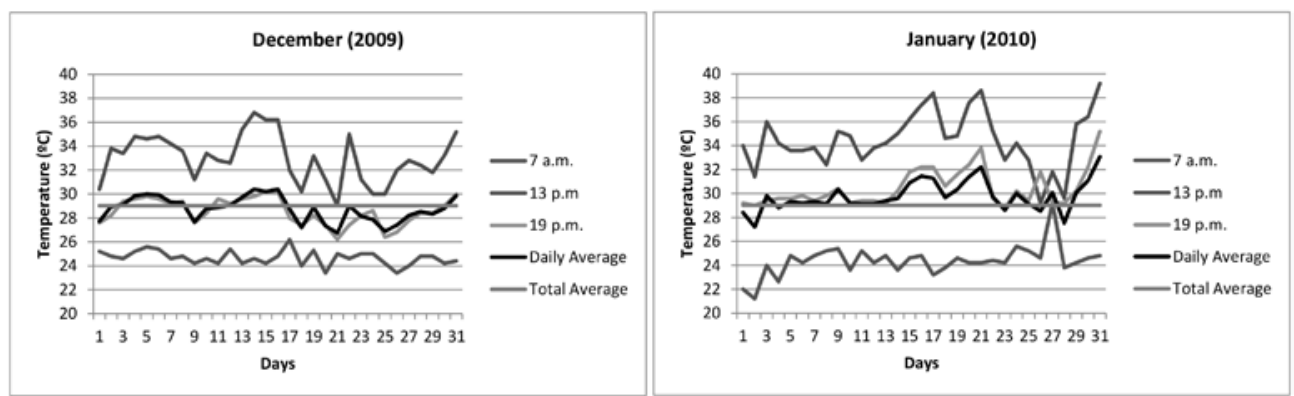

Figure 2. Temperature variation in the study area during the months December (2009) and January (2010), Ambalema (Colombia).

Source: Authors based on the weather station from Pajonales Company SA.

The average values indicates that cows generally traveled longer distances in warm period $(7.4 \mathrm{~km})$ vs. $6.1 \mathrm{~km}$ in the hot period. Data show that the animals traveled further under warm period, particularly the Brahman cows; there are also statistical differences between
$\mathrm{F} 1$ and $\mathrm{Br}$ cows in the lower temperatures $(\mathrm{p} \leq 0,05)$. Average distances traveled by the animals (both $\mathrm{F} 1$ and $\mathrm{Br}$ ) at higher and lower temperature, in the hot period were not statistically different (Figure 3).

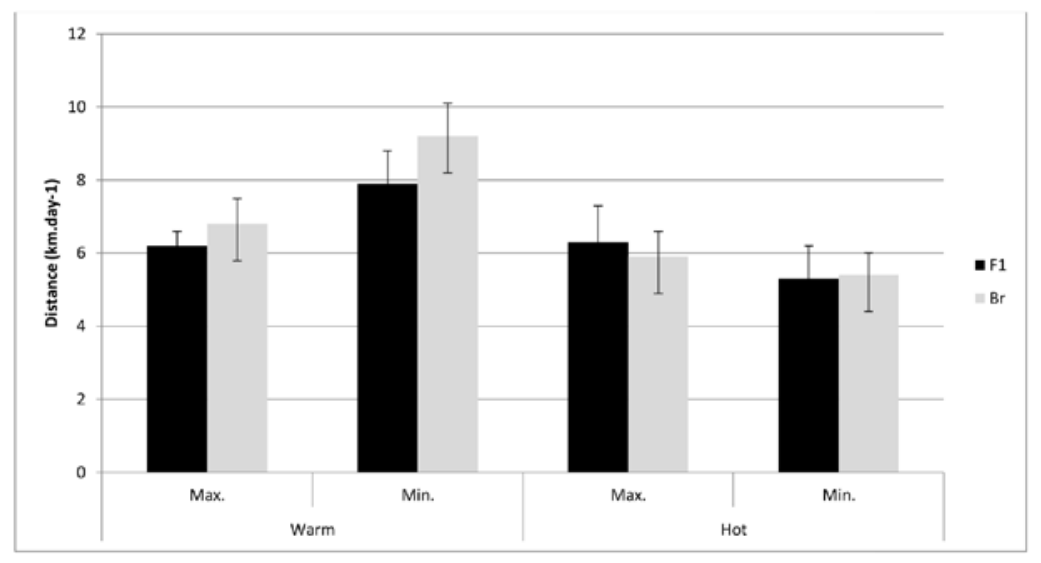

Figure 3. Distance traveled (km. Day-1) by cows (F1: Holstein $x$ Brahman, Br: Brahman) in warm period and hot period under maximum (Max) and minimum temperatures (Mín.) in Tolima, Colombia. (Authors of this research) 
Result show that a total amount of 2441 observations classified as activity ( $\mathrm{T}$ and G) and No Activity (R) were performed. An analysis between observed positions and predicted data shows that $72 \%$ were coincident in the observations of No activity (resting). The data, statistically analyzed with Chi-square test, shown a dependence between observed and predicted data $(\mathrm{p}=$ $0.001)$. In average, cows devoted $6 \mathrm{~h}(25 \%)$ traveling; $8 \mathrm{~h}(33 \%)$ grazing and $10 \mathrm{~h}(42 \%)$ resting. Generally, on both warm and hot period, cows prefer to devote more proportion of time in resting.

Table 1 show statistical differences between warm and hot periods in the di- fferent activities of cow's performance. Non statistical differences were detected between breeds and interaction breed * period weather $(\mathrm{p}>0,05)$.

Mainly, $\mathrm{Br}$ cows showed statistical differences in the time spent traveling, with a significant advantage in the warm period versus the hot period. On the contrary, the time dedicated to rest is greater under the hot days compared to warm days. There were no statistical differences between the two periods for the grazing activity. The F1 cows no presented statistical differences in the daily activities between the weather periods.

Tabla 1. Animal activity under warm and hot period of F1 (Holstein x Brahman) and Brahman cows in Tolima, Colombia.

\begin{tabular}{|c|c|c|c|c|c|}
\hline \multirow{3}{*}{ Breed } & \multirow{3}{*}{ Activity } & \multirow{2}{*}{\multicolumn{2}{|c|}{$\frac{\text { Hot }\left(31^{\circ} \mathrm{C}\right)}{\text { Ave. (h.day-1) }}$}} & \multirow{2}{*}{\multicolumn{2}{|c|}{$\begin{array}{c}\text { Warm }\left(27^{\circ} \mathrm{C}\right) \\
\text { Ave. (h.day-1) }\end{array}$}} \\
\hline & & & & & \\
\hline & & Mean & SD & Mean & SD \\
\hline \multirow{3}{*}{$\mathrm{Br}$} & $\mathrm{T}$ & $7,68 a$ & 0,57 & $9,14 b$ & 0,54 \\
\hline & G & $4,22 a$ & 0,25 & 4,92a & 0,57 \\
\hline & $\mathrm{R}$ & $11,94 a b$ & 1,05 & $9,96 a$ & 0,00 \\
\hline \multirow{3}{*}{ F1 } & $\mathrm{T}$ & $7,16 a$ & 0,28 & $8,16 a b$ & 0,06 \\
\hline & G & $4,28 a$ & 0,06 & $4,72 \mathrm{a}$ & 1,19 \\
\hline & R & $12,56 b$ & 0,07 & $11,14 a b$ & 1,27 \\
\hline
\end{tabular}

Note: Different letters in the same row mean significant differences between weather periods $(\mathrm{P}<0.05)$ Ave. average; T Traveling; G Grazing and R Resting.

Source: Authors of this research. 
On the other hand, the results of TC analyze, shown that the silvopastoral system had a gradient of tree cover from $<20 \%$ to $>80 \%$, in a design of scattered trees on a monospecific pasture of $\mathrm{Bo}$ thriochloa pertusa. Thus, 47\% (25.4 ha) of pasture had a poor tree cover $(<20 \%)$, which means that almost half of the paddock has a tree cover oscillating between low and very high coverage.

Analyzing the $45,755 \mathrm{CP}$, which ones represent $\mathrm{CP}$ every five minutes, the data indicate that the cows were kept longer on areas with poor TC, but, retention of animals at Low TC is not negligible. However, the $\mathrm{CP} /$ area ratio showed a higher presence of cows in the Low TC, taking into account that this area (TC: $20-$ $40 \%$ ) represents only $21 \%$ of the field; it is suggest that this area was the most visited, as it presented 1035.19 CP.ha-1, compared to 923.68 CP.ha-1 on poor tree cover. Actually, it is related with the availability to produce edible biomass, as was evidenced that, these areas had more quantity of fodder dry matter (Figure 4) with statistical differences ( $\mathrm{p}=0.0001)$ under different TC.

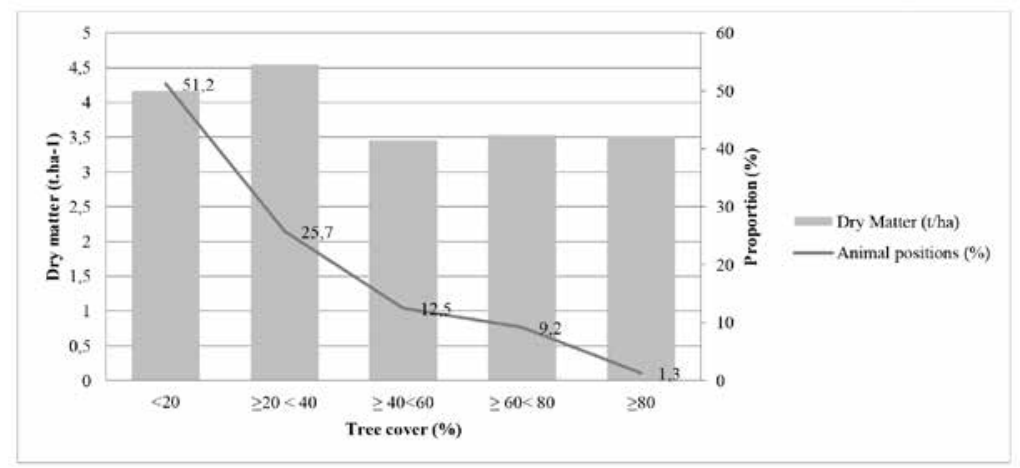

Figure 4. Edible biomass (t. ha-1) and animal positions under different tree cover in a pasture from Tolima, Colombia.

Source: Authors of this research.

Statistically it is confirmed that there is an inverse relationship of dependence between the positions of the cows and the tree canopy cover $(\mathrm{R}-0,73)$. The coefficient of determination of (R2 0,53$)$ indicates that the tree cover can explain in $53 \%$ the positions of the cattle on the greed, by mean an exponential model: $28095,82{ }^{\star} \exp \left(-0,09{ }^{\star} \mathrm{TC}\right)+5161,44$ ${ }^{\star} \exp \left(-0.01^{\star} \mathrm{TC}\right)$ (Figure 5). 


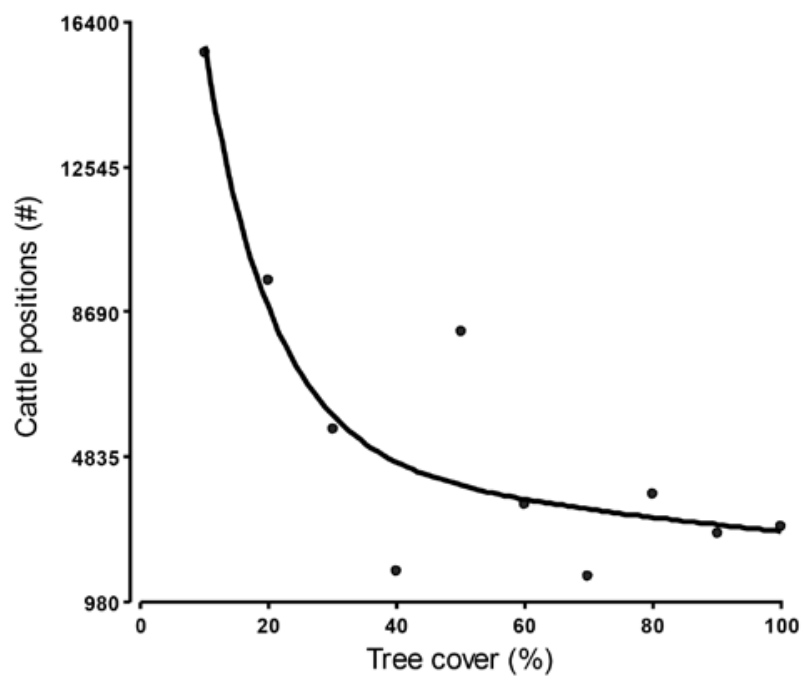

Observed data —Predicted data

Figure 5. Relationship between animal positions and tree cover represented in an exponential model. Source: Authors of this research.

On the other hand, the results indicate that there were statistical differences $(\mathrm{p}<0.05)$ in the number of visits to water trough area, between high tempera- tures and low temperatures days. There were no differences between breeds $(\mathrm{p}>$ 0,005) (Table 2).

Table 2. Permanence of cows on surroundings water trough (50 $\mathrm{m}$ diameter), in days of higher and lower temperatures.

\begin{tabular}{c|c|c|c}
\hline \multicolumn{4}{c}{ Periods (\# visits) } \\
\hline Breed & Warm & Hot & Total \\
\hline Br & $3.33 \pm 4.2 \mathrm{a}$ & $11.00 \pm 1.00 \mathrm{~b}$ & $7.8 \pm 4.6 \mathrm{a}$ \\
F1 & $4.33 \pm 3.8 \mathrm{ab}$ & $11.33 \pm 1.2 \mathrm{~b}$ & $7.2 \pm 5.0 \mathrm{a}$ \\
Total & $3.8 \pm 3.6 \mathrm{a}$ & $11.2 \pm 0.91 \mathrm{~b}$ & \\
\hline
\end{tabular}

Source: Authors of this research.

Note:Means with the same letter in the row are not significantly different $(\mathrm{p}>0.05)$. 


\section{Discussion}

This study, based on the comparison between the data of direct observation and data obtained from GPS, demonstrated effectiveness of remote sensors for tracking of cows on the field and to determine the grazing distribution, similar to report of Putfarken et al. (16). Also, the relationships between TC and CP shows an association, similar to data reported by Mora-Delgado (17), whom suggest that the animals prefer areas of pasture with low and intermediate canopy cover. They found a significant negative exponential relationship between TC and relative use of grid cells by cattle $(y=450,41$ e -12.329 $\mathrm{x}$ ); thus, tree cover explained $50,1 \%$ of the variation in relative use by cattle of the 1 ha woodland grid cells.

On the other hand, similarly to others studies, in this research work our results suggest that the breeds most adapted to less favorable environmental conditions, present a behavior that indicates a better capacity to search for food and welfare. Peineti et al. (18) affirm that mestizo cattle with indicus or Creole breed blood make better use of extensive desert fields, if compared with the more common British breeds. Also, has been documented testimonies of New Mexican ranchers that animal adapted to aggressive conditions seem better performance to the hot temperatures (19). Some reports of scientific literature support this statement: British cattle grazed longer per day than creole cattle (10.6 versus 9.82 hours/day, respectively; $\mathrm{P}<.0001$ );

British cattle also traveled less each day (6.87 versus $8.08 \mathrm{~km} /$ day, respectively; $P$ $<.0001)(20)$.
Data of this work are consistent with other studies in subtropical and tropical areas. In New Mexico (USA), Lipka et al. (21) reported bulls Angus traveling $10.0 \mathrm{~km}$.day- $1 \pm 0.7 \mathrm{SE}$, while cows (Angus and Angus x Hereford) traveled $7.0 \mathrm{~km}$.day-1 \pm 0.2 SE. Distance traveled by bulls per day varied among days of the breeding season, but there was no consistent pattern during the season distances traveled under subtropical conditions; another report showed that daily travel distance was about $5,17 \mathrm{~km}$ day-1 in Oregon, USA (22).

Respect to activity of cattle used in this research, the data are not very far from of daily activity reported in studies with Charolais cattle of 6.1 h.day-1 in grazing and 9.2 h.day-1 resting (23), unlike those reported by Mora-Delgado et al. (7) with Holstein cows in the temperate area of United States, where the cows were grazing (51\%), resting (43\%) and traveling $(6 \%)$. Probably, the variability in the activity is governed by both biotic and abiotic conditions. Thus, other authors report that both breed and season affect the behavior of cattle foraging in semi-natural grasslands. Weather is the most important factor, although genetic composition also showed differences, thus, traditional breeds had a higher level of total activity and traveling than the commercial heifers (24). The bos taurus grazing activity decreases in hot environments, being more marked in animals with black layer (25).

Although in this study there were no statistical differences in daily activity, between breed lines, the data suggest a 
slight tendency in Br animals to have more activity under less favorable environmental conditions, similar to desert, expressed in a longer time spent in both foraging and pick up food ( $\mathrm{T}$ $+\mathrm{G})$.

But the cattle try to keep a trade-offs between decisions related to feed consumption or select shaded areas for to get comfort. This trend is confirmed by the findings of Polania (26), who reports that animals prefer more coverage areas at night, where there is less dry matter available. This may be explained in a strategy to protect themselves from the cold, as suggested by the study of Black-Rubio et al. (3) in subtropical areas Chihuahua desert, where cows were kept in wooded areas when temperatures fell below $4{ }^{\circ} \mathrm{C}$ for four consecutive days. To this, Peineti et al. (18) report that better adapted animals (Creole) avoided sites with high woody density while non-adapted animals (Angus) did not avoid these sites.

Likely, cattle, in a trade-offs situation, randomly selects both habitats, searching greater availability of biomass and shade for to get comfort.

Brizuela et al (27) and Stafford-Smith (28) agree that grazing decisions occur within a hierarchy of physiological needs of an animal, according to this author, demands for thermoregulation, for example, take precedence over nutritional needs. Under intense heat, exceeding $32{ }^{\circ} \mathrm{C}$, cattle may take up to $8 \mathrm{~h}$ in the vicinity of water sources, ruminating, resting and drinking (29). This behavior was documented by Polania et al. (26),who reported that cows remained during the hours of more intense heat in surrounding areas to drinking. In fact, it has been reported that cattle can spend only 4 minutes a day consuming water but may spend 10 times more time lounging around the water source (28). Comparing between breeds, British cattle remained closer to water and had significantly smaller home ranges than creole cattle (20).

Peineti et al. (18) suggest that water is an important factor determining foraging distribution, as either to adapted and non-adapted breeds to landscape, mainly, distance to water was the most important foraging predictor of animal grazing distribution. In arid and semi-arid areas, sources of water and shade are often limited, which also affects selection of feeding sites. After watering and resting, animals must decide where to begin the next grazing bout (29).

\section{Implications}

The study of bovine performance in ter$\mathrm{ms}$ of biotic and abiotic factors is an important contribution to understanding the dynamics of animals in search for food under grazing conditions and plan production systems compatible with animal welfare. Cattle regulate its daily activity as a function of the weather conditions, especially ambient temperature. It is noteworthy that Bos indicus animals have greater ability to travel more distances in hot seasons, unlike F1 who prefer to stay more time resting. Results suggest that the animals prefer areas of pasture with low and intermediate ca- 
nopy cover, however, additional studies are required to clarify the relationships of grazing cattle and weather conditions and tree cover, and how determinant these are in the animal performance in different breed's cattle.

\section{References}

1. George M, Bailey D, Borman M, Ganskopp D, Surber G, Harris N. Factors and practices that influence livestock distribution. Rangeland Manegement Series, University of California, Publication 8217. 2007:20 p.

2. Blackshaw JK, Blackshaw AW. Heat stress in cattle and effect of shade on production and behaviour: a review. Aust. J. Exp. Agr. 1994;34:285-295.

2. Bailey DW, Gross JE, Laca EA, Rittenhouse LR, Coughenour MB, Swift DM, Sims PL. Mechanisms that result in large herbivore grazing distribution patterns. Journal of range management archives. 1996;49 (5):386-400.

3. Black-Rubio C, Cibils A, Endecott R, Petersen M, Cox S. Cattle feeding site selection in pastures with a mosaic of intact and cleared PJ woodlands. USDA Forest Service Proceedings RMRS. 2008:51p.

4. Depew JJ. Habitat selection and movement patterns of cattle and white-tailed deer in a temperate savanna. [Thesis for Master of Science]. Texas: A\&M University; 2004:71 p.

5. Ganskopp D. Manipulating cattle distribution with salt and water in large aridland pastures: a GPS/GIS assess-ment.

36 Applied Animal Behaviour Science. 2001; 73: 251-262. Doi:10.1016/S01681591(01)00148-4.

\section{Acknowledgements}

To Pajonales's Agricultural enterprise and to Central Research Office of Tolima University.

6. Ungar ED, Henkin Z, Gutman M, Dolev A, Genizi A, Ganskopp D. Inference of animal activity from GPS collar data on free-ranging cattle rangeland ecol. 2005; Manage 58:256-266.

7. Mora-Delgado J, Nelson N, Fauchille A, Utsumi S. Application of GPS and GIS to study foraging behavior of dairy cattle. Agronomía Costarricense. 2016;40(1): 81-88.

7. Mora-Delgado J, Cibils A, Rubio CM, Peinetti R, Cooper BF, Petersen MK, Cox $\mathrm{SH}$. How do monitoring cattle movement in a mosaic of wooded and open areas using GPS in conjunction with GIS? Revista Colombiana de Ciencia Animal. 2013;6(1):107-111.

8. Ganskopp D, Bohnert D. Do pasture-scale nutritional patterns affect cattle distribution on rangelands? Rangeland Ecol. 2006. Manage 59:189-196.

9. Schwager M, Anderson DM, Butler Z, Rusa D. Robust classification of animal tracking data. Computers and Electronics in Agriculture. 2007;56(1):46-59.

10. Moen R, Pastor J, Cohen Y, Schwartz CC. Effects of moose movement and habitat use on GPS collar performance. Journal of Wildlife Management 1996. 60:659-668.

11. Ganskopp DC, Jonhson DD. GPS Error in studies addressing animal movements and activities. Rangeland Ecol. 2007. Manage 60:350-358. 
12. Liu T, Green AR, Rodríguez LF, Ramírez BC, Shike DW. Effects of number of animals monitored on representations of cattle group movement characteristics and spatial occupancy. Cited 2015. PLoS ONE 10(2): e0113117. Available from https:// doi.org/10.1371/journal.pone.0113117.

13. Haydock KP, Shaw NH. The comparative yield method for estimating dry matter yield of pasture. Australian Journal of Experimental Agriculture and Animal Husbandry. 1975;15(76):662-670.

14. T'Mannetje L, Haydock KP. The dry-weight rank method for the botanical analysis of pasture. Journal of the British Grassland Society. 1963;18(4):268-275.

32. Tompkins N, O'Reagain P. Global positioning systems indicate landscape preferences of cattle in the subtropical savannas. Rangeland Journal 29. 2007:217-222. Doi:10.1071/RJ07024.

15. Di Rienzo J.A., Casanoves F., Balzarini M.G., Gonzalez L., Tablada M., Robledo C.W. InfoStat, versión 2008, Grupo InfoStat, FCA, Universidad Nacional de Córdoba, Argentina. 2008. 336 p.

16. Putfarken D, Dengler J, Lehmann S, Härdtle W. Site use of grazing cattle and sheep in a large-scale pasture landscape: A GPS/GIS assessment. Applied Animal Behaviour Science. 2008;3: Issues 1-2, 54-67.

18. Peineti R, Fredrickson EL, Peters D, Cibils A, Roacho-Estrada O, Laliberte AS. Foraging behavior of heritage versus recently introduced herbivores on desert landscapes of the American Southwest Ecosphere. May 2011;2(5); Article 57: 1-14. Doi:10.1890/ES11-00021.1

19. Moreno A. In the Southwest, a sustainable breed of cattle. High Country News. Nov 2, Cited 2017. Available from https://www. hcn.org/articles/state-of-change-in-the-southwest-a-sustainable-breed-of-cattle.

20. Roacho JO, Fredrickson E, Bezanilla GA, Peinetti R, Gonzalez AL, Rios R. A comparison of grazing behavior between desert adapted mexican criollo cattle and temperate british breeds using two diverse landscapes in New Mexico and Chihuahua. [Abstract]. Louisville, Kentucky: Society for Range Management, Building Bridges: Grasslands to Rangelands; January 26-31, 2008:p. 2379. CDROM.

21. Lipka AM, Bailey DW, Lunt ST, Thomas M, Russell M. Grazing distribution patterns of beef bulls and cows during the breeding season in Central New México. Corona Range and Livestock Research Center. 2011.

22. Johnson $D E$, Wilson $M$, Wilson $K D$, Larson LL, Williams J, Ndzeidze SK, Del Curto T, Clark PE. Spatial behavior and distribution of cattle grazing riparian zones in Northeastern Oregon. 2009:3-4.

23. Gary L.A., Sherritt G.W., Hale E.B. 1970. Behavior of Charolais cattle on pasture. J. Anim. Sci. 30:203-206

24. Hessle A, Rutter M, Wallin K. Effect of breed, season and pasture moisture gradient on foraging behaviour in cattle on semi-natural grasslands. Applied Animal Behaviour Science, 2008;111(1-2):10819. DOI:10.1016/j.applanim.2007.05.017.

25. Valle A, Velázquez J. Importancia del porcentaje de pelaje negro en animales holstein sobre el proceso adaptativo. II. comportamiento en pastoreo. Agronomía Tropical. 1980;30(1-6):181-200.

26. Polanía Y, Mora-Delgado J, Serrano $R$, Piñeros R. Movimiento de ganado en pastoreo en un sistema silvopastoril del valle cálido del Magdalena tolimense (Colombia). Revista Colombiana de Ciencia Animal. 2013; 6 (1). 58-66.

27. Brizuela, MA, Cid, MS, Cibils, A. Interacción planta-animal en el contexto de sistemas productivos desarrollados en distintos ambientes ecológicos. En: Primer Congreso Internacional de Producción Animal Especializada en Bovinos. 2015; Maskana, UC. 
28. Clawson JE. The use of off-stream water developments and various water gap configurations to modify the watering behavior of cattle. [MSc Thesis]. Oregon State: 1993.

28. Stafford-Smith, DM. Modeling: three approaches to predicting how herbivore impact is distributed in rangelands. New Mexico Agr. Exp. Sta.Reg. Res. Rep. 628, Las Cruces, USA; 1988.
29. Bailey DW, Provenza FD. Mechanisms determining large-herbivore distribution. In: Prins HHT, Van Langevelde F. (eds). Resource Ecology. Springer, Dordrecht, Wageningen UR Frontis Series; 2008:23.

29. Bavera GA. Curso de producción bovina de carne. Córdoba, Argentina: Facultad Agronomía y Veterinaria, Universidad Nacional de Río Cuarto. 2004. Cap IV, Comportamiento etológico de bovinos de carne. 